\title{
APPLICATION OF THE GRAVITY FLOW THEORY TO THE PERGOLATION OF MELT WATER THROUGH FIRN
}

\author{
By W. Аmbach, M. Blumthaler, and P. Kirchlechner \\ (Institut für Medizinische Physik, Universität Innsbruck, Müllerstrasse 44, A-6o2o Innsbruck, \\ Austria)
}

\begin{abstract}
Application of the gravity flow theory to the percolation of melt water through the firn in the accumulation area of a temperate glacier explains the occurrence of shock fronts in the melt-water flux. The time of propagation of a shock front moving from the surface through the entire firn was calculated under various assumptions. Various time input functions of melt-water flux at the surface with constant total input volumes yield only slight differences in the time of propagation of the shock front at greater depths. The dependence of the time of propagation of a shock front on the input volume, on snow parameters, and on the total thickness of the firn was calculated. An approximately linear relation was found to exist between the time of propagation of a shock front moving through the firn and the total thickness of the firn. The drainage of melt water from the firn after the summer ablation period is also quantitatively explained by the gravity flow theory. All results are in good agreement with experimental data.

RÉsumé. Application de la théorie de l'écoulement gravitaire à la percolation de l'eau de fusion à travers le névé. L'application de la théorie des écoulements gravitaires à la percolation des eaux de fusion à travers le névé dans la zône d'accumulation d'un glacier tempéré, explique qu'il puisse se produire des à-coups dans le flux d'eau de fusion. Le temps de propagation d'un front d'écoulement depuis la surface jusqu'à la totalité du névé a été calculé sous différentes hypothèses. Différents types de modulation dans le temps des apports d'eau de fusion en surface pour un apport total constant ne provoquent que de faibles variations dans le temps de propagation du front d'écoulement aux plus grandes profondeurs. On a calculé comment le volume des apports, l'état de la neige et l'épaisseur totale du névé, influait sur le temps de propagation du front d'écoulement. On a trouvé une relation à peu près linéaire entre le temps de propagation du front d'écoulement à travers le névé, et l'épaisseur totale de celui-ci. La vidange de l'eau de fonte à partir du névé après la période d'ablation estivale est aussi expliquée quantitativement par la théorie de l'écoulement gravitaire. Tous les résultats sont en bon accord avec les données expérimentales.

Zusammenfassung. Die Anwendung der gravity flow Theorie auf den Sickerfluss des Schmelzwassers durch den Firnkörper. Die Anwendung der gravity flow Theorie auf den Sickerfluss des Schmelzwassers durch den Firnkörper des Akkumulationsgebietes eines temperierten Gletschers erklärt das Auftreten von Schockfronten im Schmelzwasserfluss. Die Laufzeit einer Schockfront von der Oberfläche durch den gesamten Firnkörper wurde unter verschiedenen Annahmen berechnet. Bei gleich grossem Schmelzwasservolumen als Input an der Oberfläche und verschiedenen zeitlichen Inputfunktionen ergeben sich in grösserer Tiefe nur geringe Unterschiede für die Laufzeit der Schockfront. Die Abhängigkeit der Laufzeit der Schockfront vom Inputvolumen, von Schneeparametern und von der Gesamtmächtigkeit des Firnkörpers wurde berechnet. Zwischen der Laufzeit der Schockfront durch den Firnkörper und der Gesamtmächtigkeit des Firns ergibt sich eine annähernd lineare Beziehung. Die Abnahme des Schmelzwasserflusses im Firnkörper am Ende der sommerlichen Ablationsperiode wurde ebenfalls durch die gravity flow Theorie quantitativ erklärt. Alle Ergebnisse sind mit experimentellen Daten in guter Übereinstimmung.
\end{abstract}

List OF SYMBOLS

\begin{tabular}{|c|c|c|}
\hline & & \\
\hline$a$ & $\mathrm{~m}^{-1} \mathrm{~s}^{-1}$ & constant: $5.47 \times 10^{6} \mathrm{~m}^{-1} \mathrm{~s}^{-1}$ for water at $0^{\circ} \mathrm{C}$ \\
\hline$d$ & $\mathrm{~m}$ & mean grain size \\
\hline$k$ & $\mathrm{~m}^{2}$ & permeability at maximum saturation \\
\hline$n$ & & power (cf. Equation (I)) \\
\hline$q$ & $1 / \mathrm{h}$ & melt-water flow \\
\hline$q_{0}, q_{\max }$ & $1 / \mathrm{h}$ & $\begin{array}{l}\text { initial flow and maximum flow respectively } \\
\text { saturation (water volume/pore volume) }\end{array}$ \\
\hline$t, t_{0}$ & s & time and initial time respectively \\
\hline$S^{\star}, S_{\mathrm{i}}$ & & effective saturation and irreducible saturation respectively \\
\hline$u$ & $\mathrm{~m}^{3} / \mathrm{m}^{2} \mathrm{~s}$ & water flux \\
\hline$u_{\max }$ & $\mathrm{m}^{3} / \mathrm{m}^{2} \mathrm{~s}$ & amplitude of sinusoidal input flux \\
\hline$z$ & $\mathrm{~m}$ & depth, positive in the direction of gravity \\
\hline$\phi$ & & porosity (pore volume/total volume) \\
\hline $\begin{array}{r}\phi_{0}, \phi_{24} \\
\rho_{\mathrm{i}}, \rho_{\mathrm{W}}\end{array}$ & $\mathrm{kg} / \mathrm{m}^{3}$ & $\begin{array}{l}\text { porosity at the surface and at } 24 \mathrm{~m} \text { depth of firn respectively } \\
\text { density of ice and of water respectively }\end{array}$ \\
\hline
\end{tabular}




\section{INTRODUCTION}

The gravity flow theory was applied by Colbeck and Davidson (1973) and by Denoth and others ( $1979[\mathrm{~b}])$ for describing the percolation of melt water through homogeneous snow. In this theory it is assumed that percolation through snow is caused by gravity alone. Phenomena due to capillary forces are neglected (Colbeck, I97I).

Gravity flow theory is based on Darcy's law. It is furthermore assumed that the relative permeability of the water phase is related to the saturation by a power law. ${ }^{*}$ The flux $u$ then depends on the effective saturation $S^{\star}$ as follows:

$$
u=a k S^{\star n},
$$

where $a$ is a constant and $k\left(\mathrm{~m}^{2}\right)$ is the permeability at maximum saturation. The power $n$ probably depends on the stage of metamorphosis (Denoth and others, I979[a], [b]). Between the saturation $S$, the irreducible saturation $S_{\mathrm{i}}$, and the effective saturation $S^{\star}$, the relation is

$$
S^{\star}=\frac{S-S_{1}}{\mathrm{I}-S_{\mathrm{i}}} .
$$

This relation combines with the continuity equation to give :

$$
n(a k)^{\mathrm{I} / n} u^{(n-\mathrm{I}) / n} \frac{\partial u}{\partial z}+\phi\left(\mathrm{I}-S_{\mathrm{i}}\right) \frac{\partial u}{\partial t}=\mathrm{o},
$$

where $z$ is the depth, positive in direction of gravity, $t$ the time, and $\phi$ the porosity.

In the present paper, the formulation of gravity flow theory according to Colbeck and Davidson (1973) and Denoth and others (1979[b]), is applied to the percolation of melt water through firn in the accumulation area of a temperate glacier with non-uniform porosity. Thus a linear depth profile of porosity is assumed, inhomogeneities of firn are, however, neglected. Gravity flow theory is applied for the following analyses:

the propagation of the shock front for various histories of melt-water input at the surface, the influence of snow parameters on the propagation of the shock front, and

the drainage of melt water from the firn after the summer ablation period.

\section{ANALysis of the SHOck Front by means of the GRAVIty FlOW THEORY}

The formation of a shock front in the percolation of melt water may be explained qualitatively in the following simple manner: the percolation velocity of melt water increases with increasing flux. Larger fluxes that occur at a later time may thus catch up with smaller, earlier fluxes. The confluence may cause a sudden increase in the melt-water flux, which is called a shock front.

Figure I gives an example: two positive half-waves of a sinusoidal function each of $\mathrm{I} 2 \mathrm{~h}$ duration (dashed curve) are assumed for the melt-water input at the surface. The resulting melt-water flux at a depth of $24 \mathrm{~m}$ is shown versus time (solid curve). After $77 \mathrm{~h}$ and ror h, sudden increases of melt-water flux occur which represent the shock fronts. This variation of the melt-water flux, was calculated by means of the gravity flow theory assuming a linear depth profile of porosity. The analysis was made by means of the method of characteristics as applied to differential equation (2).

\footnotetext{
* This relation is attributed in the hydrological literature to S. F. Aver'yanov in a paper in Russian entitled "Concerning the permeability of subsurface soils in the case of incomplete saturation", Inzhenernyy Sbornik, Tom 7, 1950, but we have been unable to see the original paper. A briefer account appeared in Aver'yanov (I949).
} 


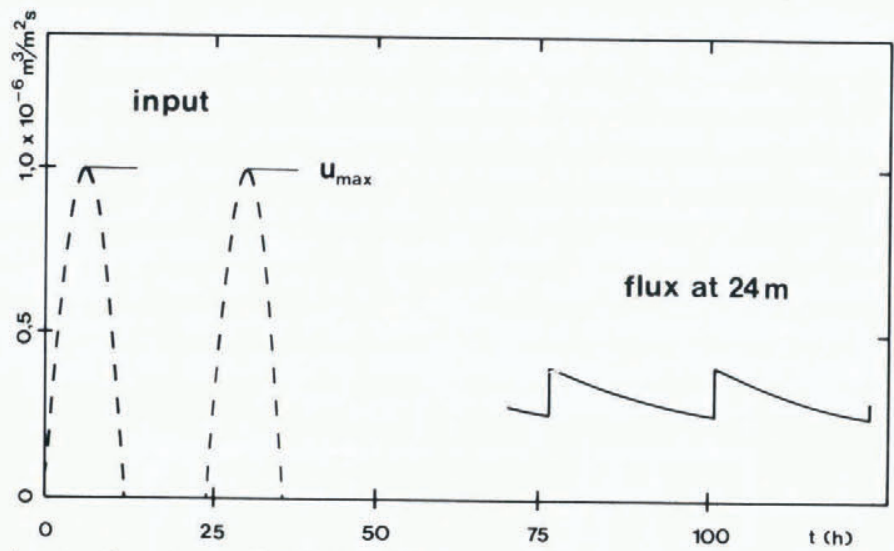

Fig. I. Calculated melt-water flux at $24 \mathrm{~m}$ firn depth (solid curve) and time function of the melt-water input flux at the surface (dashed curve). The calculation was based on the following assumptions: amplitude of the melt water input flux, $u_{\max }=I \times \mathrm{IO}^{-6} \mathrm{~m}^{3} / \mathrm{m}^{2} \mathrm{~s}$, mean values of snow parameters in accordance with Figure 2 , curve $\mathrm{B}$, linear porosity profile from $\phi_{0}=0.5$ at the surface to $\phi=0.1$ at the lower boundary of the firn and $n=3$ for the power in Equation $(I)$.

\section{I. Dependence of the propagation of the shock front on the input function}

The propagation of the shock front has been calculated for the following variations with time of the melt-water input at the surface under otherwise constant conditions:

a sinusoidal input function (positive half-wave),

a semicircular input function, and

a triangular, non-symmetric input function.

It was furthermore assumed that the total daily volume of the melt water is constant irrespective of the input function. According to Figure $\mathrm{I}$, the shock front at a depth of $24 \mathrm{~m}$ is observed after about $77 \mathrm{~h}$. The times at which the shock fronts occur with various input functions may differ by up to $3 \mathrm{~h}$. The following values of snow parameters were used for the analysis:

amplitude of the sinusoidal input flux

porosity at the surface and at $24 \mathrm{~m}$ depth, with a linear decrease

between

mean irreducible saturation

mean grain size

power in Equation ( $\mathrm{I}$ )

$$
\begin{aligned}
u_{\max } & =\mathrm{I} \times \mathrm{IO}^{-6} \mathrm{~m}^{3} / \mathrm{m}^{2} \mathrm{~s} \\
\phi_{0} & =0.5, \phi_{24}=0 . \mathrm{I} \\
S_{\mathrm{i}} & =0.03 \\
d & =\mathrm{I} .3 \times 10^{-3} \mathrm{~m} \\
n & =3
\end{aligned}
$$

The permeability at maximum saturation $k$ was calculated following the method of Shimizu (1970):

$$
k=0.077 d^{2} \exp \left[-7.8(\mathrm{I}-\phi) \rho_{\mathrm{i}} / \rho_{\mathrm{w}}\right],
$$

where $\rho_{\mathbf{i}}$ is the density of ice and $\rho_{\mathrm{W}}$ the density of water.

\subsection{Dependence of the propagation of the shock front on the amount of melt-water percolation and on the snow structure}

The time it takes to propagate a shock front through the entire firn depends on the amount of melt-water flux at the surface and on the snow parameters. First, the time of propagation was calculated for a total firn thickness of $24 \mathrm{~m}$. This depth was chosen, because theoretical results should be directly comparable with experimental data. 
Figure 2 shows the calculated relation between the time of propagation of the shock front and the assumed amplitude of the melt-water flux at the surface. The amplitude of the meltwater flux at the surface $\left(u_{\max }\right)$ given on the vertical axis, corresponds to the amplitude of a positive half-wave of a sinusoidal input function having $12 \mathrm{~h}$ duration. The curves $\mathrm{A}$ and $\mathrm{c}$ are valid for possible limiting values of the snow parameters; curve в holds for mean values. For this analysis, the firn was assumed to have a total thickness of $24 \mathrm{~m}$ with a linear profile of porosity with depth. Snow parameters are the grain size $d$ and irreducible saturation $S_{i}$. The numerical data can be read directly from Figure 2, which shows, for example, that an amplitude of the melt-water input flux of $u_{\max }=\mathrm{I} \times 1 \mathrm{O}^{-6} \mathrm{~m}^{3} / \mathrm{m}^{2} \mathrm{~s}$ and the given limiting values of the snow parameters (curves A and c) may give between 55 and $93 \mathrm{~h}$ as the time of propagation for a shock front from the surface down to $24 \mathrm{~m}$ firn depth. The assumed meltwater flux corresponds to a net ablation rate of $2.4 \mathrm{~g} / \mathrm{cm}^{2} \mathrm{~d}$.

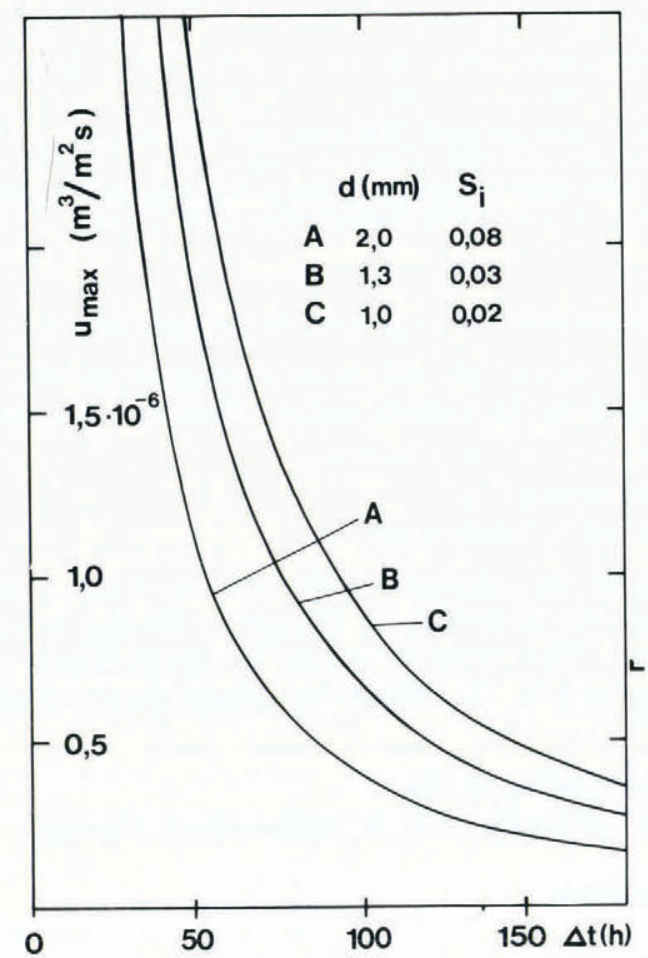

Fig. 2. Dependence of the time of propagation of the shock front down to $24 \mathrm{~m}$ firn depth on the amplitude of the melt-water flux at the surface (positive part of a sine function with a duration of input of $I 2 \mathrm{~h}$ ). The calculation was based on the following assumptions: Linear porosity profile from $\phi_{0}=0.5$ at the surface to $\phi=0.1$ at the lower boundary of the firn and $n=3$ for the power in Equation $(\mathrm{I})$. Curve B holds for mean values of the snow parameters in the firn, curves $\mathrm{A}$ and $\mathrm{C}$ give possible limiting values.

\subsection{Dependence of the propagation of the shock front on the total firn thickness}

Figure 3 gives the time of propagation of a shock front through the firn as a function of the total thickness of the firn. The curve expresses an approximately linear relation, which means that the mean velocity of propagation of the shock front is approximately independent of the total thickness of the firn. Figure 3 , for example, shows that the propagation of a shock front from the surface down to the lower boundary of the firn, i.e. $20 \mathrm{~m}$, takes $64 \mathrm{~h}$. Hence the mean rate of propagation of a shock front in the firn is $0.3 \mathrm{I} \mathrm{m} / \mathrm{h}$, and this value is approximately independent of the total thickness of the firn. 
The relation given in Figure 3 was calculated under the following assumptions:

Linear porosity profile having the values $\phi_{0}=0.5$ at the surface and $\phi=0 . \mathrm{I}$ at the lower boundary of the firn, independent of the total firn thickness.

Amplitude of the melt-water input flux at the surface $u_{\max }=\mathrm{I} \times 1 \mathrm{I}^{-6} \mathrm{~m}^{3} / \mathrm{m}^{2} \mathrm{~s}$ having the shape of the positive half-wave of a sine function.

Mean snow parameters in accordance with curve B of Figure 2.

For the accumulation area of a temperate glacier with local differences in the total thickness of firn, the time lag between snow melt at the surface and inflow of the shock front into the water table at the lower boundary of the firn may be read for any value of total firn thickness from Figure 3 .

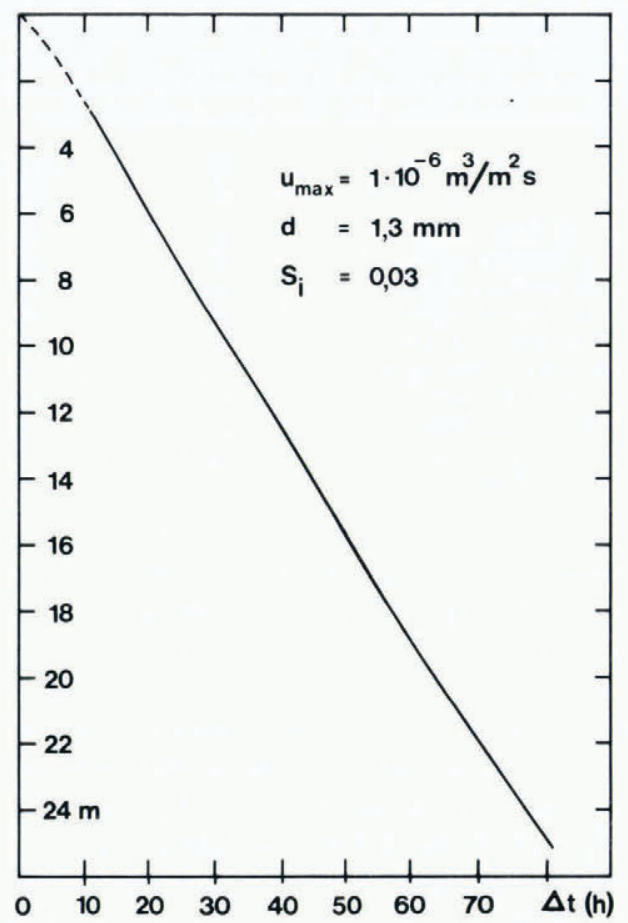

Fig. 3. Propagation time of the shock front as dependent on the total thickness of the firn layer for mean values of snow parameters (Fig. 2, curve B) and for an amplitude of the melt-water flux at the surface $u_{\max }=I \times I O^{-6} \mathrm{~m}^{3} / \mathrm{m}^{2} \mathrm{~s}$. The porosity is assumed to decrease linearly from $\phi_{0}=0.5$ at the surface to $\phi=0 . I$ at the lower boundary of the firn. $n=3$ was taken for the power in Equation $(I)$.

\section{Comparison between gravity flow theory AND EXPERImental data}

In former experimental studies a time lag of 50-IOo $\mathrm{h}$ was found between the maxima of snow melt at the surface resulting from weather conditions and the corresponding maxima of melt-water flux at the lower boundary of the firn at $24 \mathrm{~m}$ depth (Ambach and others, 1978; $\mathrm{H}$. Behrens and others, in press). These observed time lags, reviewed in Table I, are in good agreement with the time of propagation of a shock front through the firn calculated by means of the gravity flow theory. Figure 2 shows the time of propagation of the shock front to be $77 \mathrm{~h}$ for a total firn thickness of $24 \mathrm{~m}$ and for an amplitude of a melt-water flux at the surface of $u_{\max }=\mathrm{I} \times 10^{-6} \mathrm{~m}^{3} / \mathrm{m}^{2} \mathrm{~s}$, in accordance with a net ablation rate of $2.4 \mathrm{~g} / \mathrm{cm}^{2} \mathrm{~d}$, and for 
mean values of snow parameters (Fig. 2, curve B). A $\pm 50 \%$ change in amplitude of the melt-water input at the surface causes the time of propagation to change from 60 to I $20 \mathrm{~h}$. These times of propagation correspond to mean velocities of propagation of the shock front between 0.4 and $0.2 \mathrm{~m} / \mathrm{h}$. The result compares with data given by other authors on the percolation velocities of melt water through the firn of a glacier: $0.1 \mathrm{~m} / \mathrm{h}$ (Krimmel and others, I973), o. $12 \mathrm{~m} / \mathrm{h}$ (Vallon and others, 1976), $0.22 \mathrm{~m} / \mathrm{h}$ (Sharp, [1952]) and $0.35 \mathrm{~m} / \mathrm{h}$ (Ambach and others, 1978). Furthermore, measurements in natural snow cover show similar results: 0.07-0.1 $8 \mathrm{~m} / \mathrm{h}$ (Fujino, r968), $0.04-0.22 \mathrm{~m} / \mathrm{h}$ (Kobayashi, r973), and $0.30-0.66 \mathrm{~m} / \mathrm{h}$ (Wakahama, ig68).*

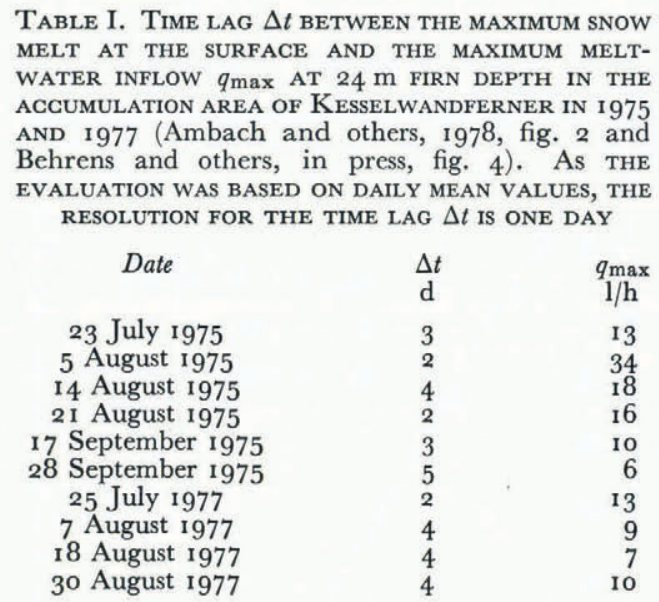

During a period of strong ablation, diurnal fluctuations of the melt-water flux in $24 \mathrm{~m}$ firn depth have been observed in the form of shock fronts in the accumulation areas of Kesselwandferner (Ambach and others, 1978, fig. 3d). These results are also in agreement with gravity flow theory. Figure 4 compares theoretical and experimental results. In these calculations, the amplitude of the melt-water input flux at the surface was again assumed to be $u_{\max }=\mathrm{I} \times \mathrm{IO}^{-6} \mathrm{~m}^{3} / \mathrm{m}^{2} \mathrm{~s}$ and again mean values of the snow parameters (Fig. 2, curve $\mathrm{B}$ ) were used. Furthermore the melt-water input flux at the surface was assumed to be periodic over several days. The daily variations of the calculated melt-water flux and the occurrence of the shock front are in satisfactory agreement with the measured results. Here, however, it must be remembered that the maximum values of melt-water flux at a firn depth of $24 \mathrm{~m}$ correspond to the melt-water input at the surface with a time lag of $3 \mathrm{~d}$. This displacement is due to the time of shock-front propagation.

Another feature confirming the applicability of the gravity flow theory to the calculation of melt-water flux in the accumulation area of an Alpine glacier is shown in Figure 5. It describes the drainage of melt water through the firn after the summer ablation period, being measured as inflow into the impermeable part of a $30 \mathrm{~m}$ deep pit (Ambach and others, 1978, fig. 2, first half of October). The decrease in the melt-water inflow can be described by the relation:

$$
q=q_{0}\left(t-t_{0}\right)^{n /(\mathrm{I}-n)}
$$

* These measurements were carried out using tracers and the data give mean particle velocities $v$. From theoretical considerations, in general $v<\left.\frac{\mathrm{d} z}{\mathrm{~d} t}\right|_{u}$, where $\left.\frac{\mathrm{d} z}{\mathrm{~d} t}\right|_{u}$ is the velocity of propagation of the shock front for a constant flux $u$. 


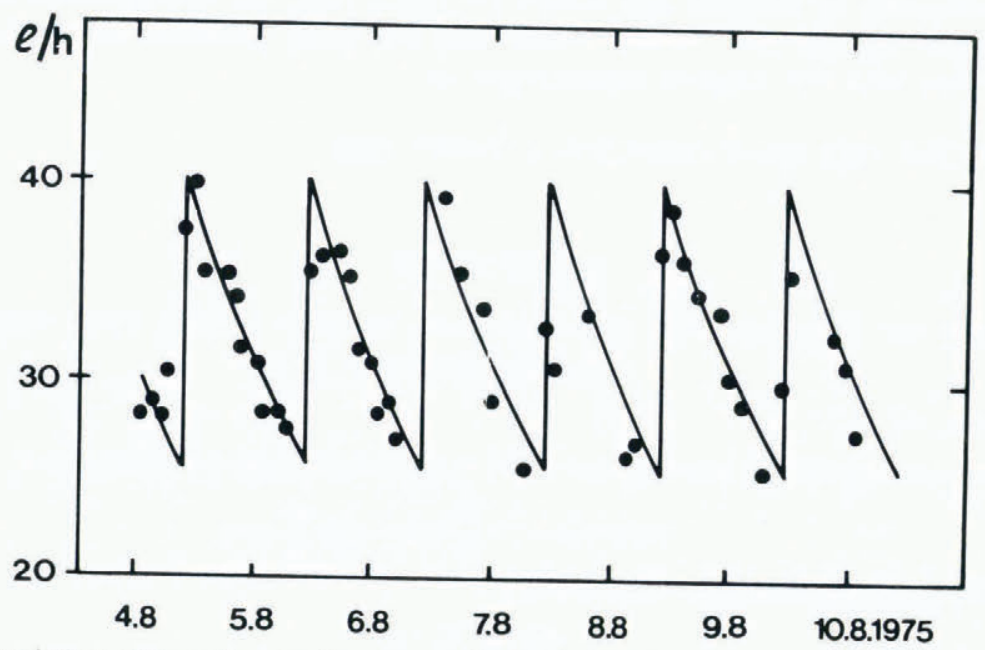

Fig. 4. Diurnal variations of the melt-water flux at $24 \mathrm{~m}$ depth calculated for mean values of the snow parameters (Fig. 2 , curve B) and for an amplitude of the melt-water flux at the surface of $u_{\max }=I \times 10^{-6} \mathrm{~m}^{3} / \mathrm{m}^{2} \mathrm{~s}$. The snow melt is assumed to be periodic over several days (positive half-wave of a sine function of $12 \mathrm{~h}$ duration). Furthermore, a linear porosity profile was assumed from $\phi_{0}=0.5$ at the surface to $\phi=0 . I$ at the lower boundary of the firn and $n=3$ for the power in Equation ( 1 ). The plotted dots are data obtained from continuous records (Ambach and others, 1978, fig. $3 d$ ).

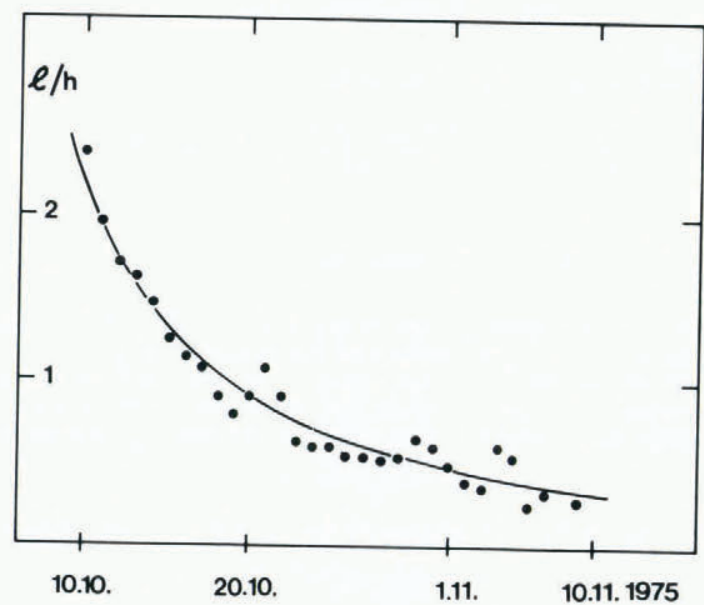

Fig. 5. Drainage of the melt-uater flux from the firn of Kesselwandferner (Ötztal Alps) after the summer ablation period 1975. The gravity flow theory (solid curve) was applied for the calculation. The data are daily means of the melt-water flux determined from continuous records (Ambach and others, 1978 , fig. 2, period: first half of October).

The above relation follows from the gravity flow theory used so far (see Appendix). In Equation (3), $q$ is the melt-water flow (expressed as volume flux in $\mathrm{m}^{3} / \mathrm{s}$ ) at the lower boundary of the firn, $t$ the time, and $q_{0}$ and $t_{0}$ are constants. The parameter $n(n>\mathrm{I})$ is the power in the relation between the relative permeability and saturation (cf. Equation (I)).

The parameters $n$ and $t_{0}$ were determined by a least-square calculation. The calculated melt-water inflow and the values measured are shown in Figure 5 . The most important result is that by optimization the power $n$ becomes $n=2.8$. Experiments made by Colbeck and Davidson (1973) on homogenized snow yielded a mean value of $n=3$. Furthermore, 
extended experiments by Denoth and others (i979[a], [b]), on homogenized snow, showed $n$ to vary between 1.4 and 4.6 . It was found that this value probably depends on the snow structure, varying with the stage of metamorphosis.

MS. received 27 July 1979 and in revised form 5 October 1979

\section{APPENDIX}

DERIVATION OF THE RELATION FOR THE DRAINAGE OF MELT WATER FROM FIRN AFTER THE ABLATION PERIOD

The conditions assumed are

(a) The differential equation for the melt-water flux in the snow is given by Equation (2)

$$
n(a k)^{\mathrm{I} / n_{u}(n-\mathrm{I}) / n} \frac{\partial u}{\partial z}+\phi\left(\mathrm{I}-S_{\mathrm{i}}\right) \frac{\partial u}{\partial t}=0 .
$$

(b) We assume a linear porosity profile in the firn

$$
\phi(z)=\phi_{0}-c z
$$

with $z=0$ at the surface and $c$ the gradient of porosity.

(c) The permeability is calculated according to Shimizu (1970)

$$
k=0.077 d^{2} \exp \left[-7.8(\mathrm{I}-\phi) \rho_{\mathrm{i}} / \rho_{\mathrm{w}}\right] .
$$

For the assumed porosity profile the permeability also depends on $z$ :

$$
k(z)=\beta \exp \left[\gamma\left(\phi_{0}-c z\right)\right],
$$

where $\beta=6.0 \times 10^{-5} d^{2}\left(\mathrm{~m}^{2}\right)$ and $\gamma=7.15$.

For the characteristics of the differential equation we find:

After integration

$$
\left.\frac{\mathrm{d} z}{\mathrm{~d} t}\right|_{u}=\frac{n(a \beta)^{\mathrm{I} / n} \exp \left[\gamma\left(\phi_{0}-c z\right) / n\right]}{\left(\mathrm{I}-S_{\mathrm{i}}\right)\left(\phi_{0}-c z\right)} u^{(n-\mathrm{1}) / n} .
$$

$$
t-t_{0}=\frac{n}{\gamma c} \exp \left[-\gamma \phi_{0} / n\right]\left\{\exp [\gamma c z / n]\left(\phi_{0}-c z+n / \gamma\right)-\phi_{0}-n / \gamma\right\} \frac{\mathrm{I}-S_{1}}{n(a \beta)^{\mathrm{I} / n}} u^{(\mathrm{I}-n) / n},
$$

where $t=t_{0}$ for $z=0$. Hence $t_{0}$ is the starting time of a certain $u$ value at the surface which is given by the input function. The starting time of the fluxes considered for drainage of the melt water from the firn after an ablation period lies immediately at the end of the last input. The starting time $t_{0}$ is assumed to be constant for all $u$ values, as the time of propagation of these $u$ values are significantly longer than the differences between the start times. Thus the above equation is valid for all $u$ values at constant $t_{0}$, and for a given depth $z$ :

$$
u=K\left(t-t_{0}\right)^{n /(\mathrm{I}-n)} \text {. }
$$

The inflow into a reservoir is obtained by multiplying by the catchment area. Hence

where $K$ and $q_{0}$ are constants.

$$
q=q_{0}\left(t-t_{0}\right)^{n /(\mathrm{I}-n)},
$$

\section{REFERENCES}

Ambach, W., and others. 1978. Untersuchungen der Wassertafel am Kesselwandferner (Ötztaler Alpen) an einem 3o Meter tiefen Firnschacht, von W. Ambach [and 9 others]. Zeitschrift für Gletscherkunde und Glazialgeologie, Bd. I 4 , Ht. I, p. $61-7$ r.

Aver'yanov, S. F. 1949. Zavisimost' vodopropitsayemosti pochvo-gruntov ot soderzhaniya v nikh vozdukha [Dependence of permeability of subsurface soils on their air content]. Doklady Akademii Nauk SSSR, Tom 69,

No. 2, p. $14 \mathrm{I}-44$.
Behrens, H., and others. In press. Neue Ergebnisse zur Bewegung des Schmelzwassers im Firnkörper des Akkumulationsgebietes eines Alpengletschers (Kesselwandferner - Ötztaler Alpen), von H. Behrens [and 7 others]. Zeitschrift für Gletscherkunde und Glazialgeologie.

Colbeck, S. C. 1971. One-dimensional water flow through snow. U.S. Cold Regions Research and Engineering Laboratory. Research Report 296. 
Colbeck, S. C., and Davidson, G. 1973. Water percolation through homogeneous snow. (In [International Hydrological Decade.] The role of snow and ice in hydrology. Proceedings of the Banff symposia, September 1972. Paris, UNESCO; Geneva, WMO; Budapest, IAHS, Vol. 1, p. 242-57. ([Publication No. 107 de l'Association Internationale d'Hydrologie Scientifique.]))

Denoth, A., and others. 1979 [a]. Some experimental data on water percolation through homogeneous snow, [by] A. Denoth, W. Seidenbusch, M. Blumthaler, P. Kirchlechner. (In Colbeck, S. C., and Ray, M., ed. Proceedings of a meeting on modeling of snow cover runoff, 26-28 September 1978, [held in] Hanover, New Hampshire. Hanover, N.H., U.S. Cold Regions Research and Engineering Laboratory, p. 253-56.)

Denoth, A., and others. I979[b]. Study of water drainage from columns of snow, [by] A. Denoth [and 5 others]. U.S. Cold Regions Research and Engineering Laboratory. Report 79-1.

Fujino, K. 1968. Sekisetsu naibu de no yūsetsu-sui no ryūka sokudo no sokutei. I [Measurement of flowing down speed of melt water in a snow cover. I]. Teion-kagaku: Low Temperature Science, Ser. A, [No.] 26, p. 87-100.

Kobayashi, D. I973. Sekisetsuchū no yūsetsusui no himaku ryūka sokudo. I [Flow-down speed of melt water in snow cover. I]. Teion-kagaku: Low Temperature Science, Ser. A, [No.] 31, p. 135-42.

Krimmel, R. M., and others. 1973. Water flow through a temperate glacier, [by] R. M. Krimmel, W. V. Tangborn, and M. F. Meier. (In [International Hydrological Decade.] The role of snow and ice in hydrology. Proceedings of the Banff symposia, September 1972. Paris, UNESCO; Geneva, WMO; Budapest, IAHS, p. 40I-I6. ([Publication No. 107 de l'Association Internationale d'Hydrologie Scientifique.]))

Sharp, R. P. [1952.] Meltwater behavior in firn on upper Seward Glacier, St Elias Mountains, Canada. Union Géodésique et Géophysique Internationale. Association Internationale d'Hydrologie Scientifique. Assemblée générale de Bruxelles, 1951. Tom. I, p. 246-53. (Publication No. 32 de l'Association Internationale d'Hydrologie.)

Shimizu, H. I970. Air permeability of deposited snow. Contributions from the Institute of Low Temperature Science, Ser. A, No. 22.

Vallon, M., and others. ${ }^{1}{ }^{1976}$. Study of an ice core to the bedrock in the accumulation zone of an Alpine glacier, by M. Vallon, J.-R. Petit, and B. Fabre. Journal of Glaciology, Vol. 1 7, No. 75, p. 13-27.

Wakahama, G. I 968 . Sekisetsu-nai ni okeru yūsetsu-sui no idō. III. Suiro ryūka sokudo himaku ryūka sokudo [Infiltration of melt water into snow cover. III. Flowing down speed of melt water in a snow cover]. Teionkagaku: Low Temperature Science, Ser. A, [No.] 26, p. 77-86. 